811.163.41'367

https://doi.org/10.18485/sj.2020.25.1.14

ЈЕЛЕНА Л. ПЕТКОВИЪ

Универзитет у Крагујевцу

Филолошко-уметнички факултет
Оригинални научни рад

Примљен: 15. 10. 2019.

Прихваћен: 15. 01. 2020.

\title{
МНОЖЕЊЕ НЕГАЦИЈА ИЗМЕЂУ РАЗЛИЧИТИХ РЕЧЕНИЧНИХ ЧЛАНОВА ${ }^{* *}$
}

Предмет проучавања у овом раду јесте појава множења негација између различитих реченичних чланова. Анализу смо провели на корпусу из различитих функционалних стилова, ексцерпирајући примере у којима се нужно јавља негирани предикат и један од следећих реченичних чланова, такође нужно у негираној форми, логички субјекат, објекат, предикатски апозитив, одредба начина или одредбени члан исказан генитивном предлошко-падежном конструкцијом са предлогом без. Циљ рада јесте да се утврде нужни и довољни услови под којима долази до множења негација између различитих реченичних чланова, у чијем се резултату добија афирмативна семантичка вредност исказа, као и да се испита како ово множење негација утиче на новонасталу афирмативну семантичку вредност исказа. Анализа је, такође, показала и бројна ограничења која онемогућавају множење негација између различитих реченичних чланова.

Кључне речи: негација, множење негација, негирани предикат, логички субјекат, објекат, предикатски апозитив, одредба начина.

*jelenapetkovic75@gmail.com

** Рад је настао у оквиру пројекта 178014 Динамика структура српског језика, који финансира Министарство просвете, науке и технолошког развоја Републике Србије. 


\section{1. УВОДНА РАЗМАТРАЮА}

О негацији као језичкој категорији постоје бројна истраживања у последњим годинама 20. и првим годинама 21. века. Она сама постала је базична тема многих синтаксичких и семантичких теорија. Таква ситуација проистиче из чињенице да је негација као језичка категорија присутна у свим језицима у свету, да показује бројне варијације у односу на начин којим се може изразити или тумачити, и треће у интеракцији је са многим другим феноменима у природним језицима, те на тај начин омогућава осветљавање различитих синтаксичких и семантичких механизама и начина на који су ове различите граматичке компоненте повезане.

Без обзира на присуство негације у свим природним језицима, ипак, језици се разликују, и синхронијски и дијахронијски, у односу на број, синтаксичку позицију и синтаксички статус формалних показатеља негације у реченици. Занимљиво је и то да се језици могу разликовати и у односу на различиту могућност интерпретације реченица које садрже више од једног негативног елемента (више у: Јесперсен 1917).

Конструкције у којима су реченични негатори не и ни најмање два пута употребљени, и то једном нужно у оквиру предиката (субпредиката), у синтаксичкој литератури се обележавају термином конструкције са двоструком негацијом, при чему се оне могу јавити и у монопредикатским и у полипредикатским реченицама. Разматрајући даље моделе синтаксичких конструкција са двоструком негацијом, примећено је да се не понашају сви модели тих конструкција исто у односу на своју семантичку интерпретацију. Наиме, у некима од ових конструкција долазиће до конгруенције или сабирања негација, под којом се подразумева слагање негираног предиката (субпредиката) и негираних универзалних квантификатора, или до множења негација или логичко-математичке негације која је дефинисана као „,negacija u logičko-matematičkom smislu, prema kojemu se udvostručenje (ponavljanje) negacije uzajamno poništava" (Симеон 1969: 893). Множењем негација добијају се афирмативни семантички еквиваленти код којих је степен семантичке еквиваленције различит у зависности од морфолошко-семантичко-синтаксичких одлика употребљених синтаксичких јединица које у таквом множењу учествују.

\section{2. МНОЖЕЬЕ НЕГАЦИЈА ИЗМЕЪУ РАЗЛИЧИТИХ РЕЧЕНИЧНИХ ЧЛАНОВА}

Множење негација не остварује се само унутар једног реченичног члана, већ је оно могуће и између два различита реченична члана, од којих један нужно мора бити негирани предикат реченице, а други реченични члан јесте 
неки негирани глаголски додатак (или његов део) одредбеног или допунског карактера. То може бити одредба начина изражена неким негираним начинским прилогом, логички субјекат уз глагол немати или не постојати, предикатски апозитив изражен негираним придевом, негирани објекат или одредбени члан исказан генитивном предлошко-падежном конструкцијом са предлогом без. Множењем негација у оваквим конструкцијама добијају се формални афирмативни еквиваленти исказа са двоструком негацијом. О међусобној (не)супституентности конструкција у којима се остварује множење негација између различитих реченичних чланова и њихових формалних афирмативних еквивалената биће речи у оквиру сваке појединачне тачке, будући да на опсег преклапања значења афирмативних и двоструко негираних исказа утичу различити фактори у зависности од тога који је реченични члан, поред предиката, негиран, као и која је синтаксичка јединица употребљена у функцији одговарајућег реченичног члана.

Наша анализа проведена је на корпусу који чине функционално и стилски различити типови текстова, ${ }^{1}$ будући да је примећено да се конструкције са множењем негација јављају у свим функционалним стиловима, додуше не увек са истом учесталошћу употребе.

\section{1 Множење негација између негираног субјекта и негираног предиката}

Множење негација између негираног субјекта и негираног предиката остварује се искључиво у једном структурном типу реченица, а то су егзистенцијалне реченице са одричним облицима глагола имати (немати) или nостојати (не постојати) у функцији предиката. До множења негација у овом типу реченица долази између (i) тог негираног глагола у функцији предиката реченице и (ii) логичког субјекта израженог супстантивном синтагмом у генитиву са негираним конгруентним атрибутом (уз глагол немати) или граматичког субјекта израженог супстантивном синтагмом у номинативу с негираним конгруентним атрибутом (уз глагол не постојати).

У функцији логичког или граматичког субјекта се, поред супстантивне синтагме са негираним конгруентним атрибутом, што је у испитиваном корпусу чешћи случај, могу употребити и негативно префигиране лексеме 2 . До множења негација, заправо, долази између негације коју садржи негирани

${ }^{1}$ Термином двострука негација означава се и вишеструка негација, у реченицама у којима се реченични негатори не и ни употребе више од два пута, при чему је негирани предикат, такође, нужни услов, будући да се она „најчешће и остварује као двострука” (Ковачевић 2002: 15).

${ }^{2}$ Под множењем негација подразумевамо математичко-логички принцип који у језику доводи до тога да два негатора употребљена у склопу једне изреке дају афирмативну семантичку вредност читавом исказу (више у: Петковић 2015). 
предикат и негације коју садржи негирани конгруентни атрибут супстантивне синтагме или негације коју садржи лексема у функцији логичког или граматичког субјекта, при чему у резултату добијамо афирмативну семантичку вредност еквивалентну изразу са множењем негација.

У највећем броју примера при семантичком преобликовању, могуће је у афирмативним еквивалентима употребити прилоге само и искључиво, „који рестрикцијом указују на универзално важење двоструко негираног исказа, што потврђује и семантичка преоблика еквивалентном реченицом с глаголом бити у глаголском дијелу именског предиката и универзалним квантификатором све у позицији конгруентног атрибута уз субјекат" (Ковачевић 2004: 180).

Нема ту несреће ${ }^{3}$ [ $\rightarrow$ Постоји ту само срећа // Све је ту срећа], пашо (И. Андрић, 132); И ту нема ничег нехуманог ${ }^{4}[\rightarrow$ И ту постоји само хумано // И ту је све хумано] (С. Басара, 357); Оцењујући да у томе нема ничег негативног [ $\rightarrow$ Oиењујући да ту постоји само позитивно // Оцењујући да је ту све позитивно], он је као сличне примере навео и италијански Фијат у Крагујевцу и словеначко Горење у Зајечару (http://www.politika. rs/rubrike/Politika/Bacevic-Ne-prepoznajem-se-u-izjavi-ministarke-Mihajlovic.sr.html); А тада више није било незаузете земље и нераскрчених шума $[\rightarrow$ А тад је постојала само заузета земьа и раскрчене шуме // Сва земља је била заузета и све шуме раскрчене] за њиве. (Д. Ћосић, 233); То је био један од оних људи за које нема неуспеха $[\rightarrow$ за које постоји само успех // за које је све успех] (И. Андрић ${ }^{1}$, 139); Ничег необичног није било $\left[\rightarrow\right.$ Постоји само обично // Све је било обично ] у томе (И. Андрић $\left.{ }^{1}, 131\right)$; Nadam se da ćemo konačno da postignemo dogovor i da ovoga puta neće biti nikakvih nepredvidivih situacija $[\rightarrow$ и да ће овог пута бити само предвидиви ситуаџија // и да ће овог пута све ситуаџије бити предвидиве] — zaključuje Mihajlovski. (Вечерње новости, 30. 8. 2011.); итд.

Множење негација између негираног предиката и логичког или граматичког субјекта израженог неким негираним категоријално и функционално преобразованим придевом није могуће у случајевима када је тај преобразовани придев одређен атрибутом исказаним односном рестриктивном реченицом, као у примеру Ali na našoj evidenciji nije bilo nezaposlenih koji su ispunjavali uslove. [ $\rightarrow$ *било је само запослених који су испуњавали услове]. (http://www.novosti. rs/vesti/naslovna/aktuelno.239.html:377754-U-potrazi-za-poslom-i-u-najudaljenijekrajeve-sveta); итд. Будући да таква односна рестриктивна реченица сужава значење негираног преобразованог придева на јединични појам, није могуће преобликовање негираног преобразованог придева у његову афирмативну варијанту са универзалним важењем.

${ }^{3} \mathrm{O}$ прагматичким разлозима који у комуникативном чину условљавају да се говорник определи за двоструко негирани исказ уместо, формално и семантички, знатно једноставнијег позитивног исказа више у: Петковић 2015.

${ }^{4}$ Множење негација унутар једног реченичног члана подразумева „употребу два негатора уз исти реченични члан” (Ковачевић 2004,169$)$ и такво се множење може остваривати или у оквиру различитих синтаксичких типова предиката или у оквиру генитивно предлошко-падежне конструкције са предлогом без (више у: Ковачевић 2004 и Петковић 2015). 


\section{2. Множење негација између негираног предиката и одредбе/допуне за начин исказане негираним начинским прилогом}

Множење негација може се остварити и између негираног предиката и негираног начинског прилога који је у функцији одредбе/допуне за начин. До множења долази између (i) негације коју садржи глагол у предикату и (ii) негације коју садржи тај начински прилог, а као производ добијамо глаголску синтагму са потврдним значењем.

... не могу се понашати неодоговорно $[\rightarrow$ морам се понашати одговорно] према грађанима који очекују да Србија испуњава обавезе које је преузела у исплати пензија, зарада у школству, здравству и другим областима (http://www.politika.rs/rubrike/Politika/ Stankovic-Politika-uslovljavanja-ne-donosi-nikome-dobro.sr.html); Nije nemoguće zaključiti $[\rightarrow$ Могуће је закључити $]$ da ovaj instrument pjesnik koristi u namjeri da oslika sve slabosti Šćepanovog karaktera. (Б. Радовић, 69); Један узрок, чије се својство не запажа непосредно $[\rightarrow$ чије се својство запажа посредно], открива се у дејству које га неминовно прати (Наслеђе 23, 80 фуснота); ...а те везе и ти услови били су сада далеко и вешто постављени да их појединац није непосредно осећао $[\rightarrow$ да их је појединаи посредно oceћao] (И. Андрић $\left.{ }^{1}, 215\right)$; I stoga smo ga tako odmah i neosporno i priznali za oružje! I stoga optuženi nije nesvesno i nije nehotice zgrabio $[\rightarrow$ свесно и намерно је зграбио] taj kobni tučak. (Достојевски, ЕК); итд.

Када се у оваквим реченицама нађе и неки одрични универзални квантификатор, будући да се ради о формално негираним предикатима, он се, при преобликовању оваквих реченица у њихове афирмативне семантичке еквиваленте, замењује одговарајућим потврдним универзалним квантификатором.

Не остварује се множење негација нужно у свакој вези негираног предиката и негираног начинског прилога. Да би до множења негација могло доћи, нужно мора доћи до остварења антонимске семантичке вредности начинског прилога. На овом се месту укрштају проблеми реченичне негације са проблемима лексичке негације ${ }^{5}$. У свим оним случајевима у којима долази само до порицања онога што је означено прилогом, али не долази до реализације његове афирмативне семантичке вредности, имамо случај литоте, што се на формалном плану показује могућношћу употребе али-антонимског наставка двоструко негиране глаголско-прилошке синтагме (уп. Ковачевић 2004: 178). Овакви двоструко негирани искази свој пандан имају у двоструко негираним неглаголским предикатима у којима је у предикативу неки негирани квалитативни антоним ${ }^{6}$, који нису у потпуности семантички еквивалентни афирма-

\footnotetext{
${ }^{5}$ Корпус су чинили текстови који припадају књижевноуметничком стилу у првом реду, али и текстови из публицистичког и административног стила, а сразмерно најмање текстови који припадају научном и разговорном функционалном стилу.

${ }^{6}$ Под негативно префигираним лексемама подразумевамо појаву познату под називом лексичка негација која представља негацију префиксацијом именичких, придевских, прилошких и заменичких речи, која се постиже домаћим префиксима не- и без- (код именица, придева и прилога) и префиксом ни- (код заменица); или страним префиксима, од којих су најчешћи $a$-, $\partial u c-, u-, u{ }^{-}$. „Све те творенице логички потпадају под негативне појмове, јер се њима означава
} 
тивним парњацима због чињенице да се негацијом једне поларне вредности не добија нужно супротна поларна вредност, већ се полазна вредност само одриче.

Украјина наглашава да „није недозвољено узимала $[\rightarrow$ није недозвољено, али није ни дозвољено узимала] гас", ... (Политика, 8.2.2009.); U tom smislu služila su dokazivanja odbrane da ona ništa od toga nije neposredno videla $[\rightarrow$ није непосредно, али није ни посредно] nego saznavala tek ,iz druge ruke”, od pripadnika UN ili samih građana. (Политика, 15.3.2008, ЕК); итд.

\section{3. Множење негација између негираног предиката и генитивне предлошко-падежне конструкције са предлогом без}

Множење негација остварује се и у оквиру глаголске синтагме са негираним глаголом у функцији предиката и генитивном предлошко-падежном конструкцијом са предлогом без. Овај тип множења негација могућ је у егзистенцијалним глаголским синтагмама са предлогом без и у глаголским синтагмама са генитивном предлошко-падежном конструкцијом са предлогом без у функцији прилошке одредбе за пропратну околност.

У негираним егзистенцијалним глаголским синтагмама централни члан је негирани егзистенцијални глагол немати/не бити или не постојати, који је употребљен у функцији предиката реченице. Уз овакав глагол у егзистенцијалним реченицама обавезно ја навођење логичког субјекта израженог беспредлошким генитивом, уз глагол немати/не бити или граматичког субјекта израженог номинативом, уз глагол не постојати. До множења негације у овом типу реченица долази, по правилу, у случајевима употребе предлошкопадежне конструкције са предлогом без у функцији неконгруентног атрибута уз именице у функцији логичког или граматичког субјекта.

Множење негација остварује се између (i) негације коју садржи егзистенцијални глагол немати/не бити или не постојати у функцији предиката реченице и (ii) имплицитне негације коју садржи предлог без у функцији неконгруентног атрибута уз именице у функцији логичког или граматичког субјекта. У резултату оваквог множења добија се потврдна реченица са глаголом имати уз који ће се остваривати граматички субјекат, при чему се неконгруентни атрибут изражен генитивном предлошко-падежном конструкцијом са предлогом без из негираног модела замењује еквивалентним објекатским беспредлошким генитивом или акузативом. У највећем броју овако преобликованих реченица уз граматички субјекат се може употребити потврдни универзални квантификатор као конгруентни атрибут, чак и у случајевима у

одсутност, односно непостојање неке особине или односа, с тим да се негативни појмови не исцрпљују у твореницама насталим негативним префигирањем” (Ковачевић 2002: 12). 
којима се није јављао негирани универзални квантификатор као конгруентни атрибут уз логички или граматички субјекат у негираном моделу.

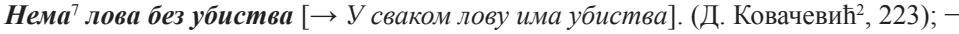
Donošenje Zakona o agenciji za borbu protiv korupcije najbolji je pokazatelj da nema vladavine prava bez efikasnih institucija [ $\rightarrow$ да има владавине права само уз ефикасне институиије] - dodao je premijer, i podsetio da je u toj funkciji i reforma pravosuđa, nova mreža sudova, dobra saradnja policije i tužilaštva. (http://www.novosti.rs/vesti/naslovna/politika/aktuelno.289. html:289046-Cement-protiv-mita 18.6.2010); Nema turizma bez brendiranja $[\rightarrow$ Tуризма има само са брендирањем]. Nema brendiranja bez vizuelnog identiteta $[\rightarrow$ Брендирања има само уз визуелни идентитет]. Nema vizuelnog identiteta bez, dugoročne i dobro organizovane strategije vraćanja и život Šumadije pre komunizma $[\rightarrow$ Визуелног идентитета има само уз дугорочну и добро организовану стратегију враћања у живот Шумадије пре комунизма]. Šumadija - Balkans as it once was. (http://alexandarlambros.wordpress.com/2014/02/15/srbijamedu-sljivama/ 18.2.2014); Ако се језик утопи, топи се са њим и народ, а без језика народа, нема народа [ $\rightarrow$ а народа има само уз језик народа]. (http:/www.glassrpske.com/kultura/ vijesti/Milos-Kovacevic-Srpski-identitet-nestaje-sa-cirilicom/146433.html 10.2.2014.); Без вавилонскихматематичара и астронома не би било ни јонских физичара $[\rightarrow$ Јонских физичара има само са вавилонским математичарима // Јонски физичари постоје јер постоје вавилонски математичари $\left.{ }^{8}\right]$. Без Вавилона не би било Атине $[\rightarrow$ Атине има само са Вавилоном // Атина постоји јер постоји Вавилон]. (Наслеђе 51, 28); итд.

У негираним глаголским конструкцијама у којима је употребљена генитивна предлошко-падежна конструкција са предлогом без у функцији адвербијалне одредбе пропратне околности, долази такође до множења негација. Множење негација се, тако, остварује између (i) негације коју садржи глагол у функцији предиката реченице и (ii) имплицитне негације коју садржи предлог без у оквиру генитивне предлошко-падежне конструкције у функцији адвербијалне одредбе пропратне околности. Резултат овог множења је реченица са потврдном глаголском конструкцијом, тј. потврдним глаголом у функцији предиката уз који се, уместо генитивне предлошко-падежне конструкције са предлогом без из негираног модела, употребљава беспредлошка инструментална конструкција или инструментална конструкција са предлогом $c a$, или акузативна конструкција са предлогом уз.

У реченицама у којима је адвербијалан одредба пропратне околности изражена генитивном предлошко-падежном конструкцијом са предлогом без и девербативном именицом, може се реконструисати потврдна пропратнооколносна клауза с везником а да (при том не).

${ }^{7}$ М. Павловић сматра да констатације Има јединства и Нема нејединства нису идентичне, јер чињеница је да глаголи јесу у семантичкој опречности, али је „нејединство” нов, посебан појам, појам ефекта порицања могућности, а не одречно схваћена ситуација" (Павловић 1967: 243).

${ }^{8}$ У овом примеру долази до функционалног преобразовања врста речи, када се једна врста речи (у овом случају придев) јавља у синтаксичкој функцији која је првенствено резервисана за неку другу врсту речи (у овом случају именицу). Но, функционално преобразовање, овде, неће имати никаквог утицаја на понашање оваквих конструкција приликом множења негација. 
Ова књига не би могла ни да настане ни да постоји у овом облику без помоћи $[\rightarrow$ је могла и да настане и да постоји само уз помоћ] коју су ми пружили, при писању, мој супруг Жарко Рошуљ и моја сестра Гордана Велмар-Јанковић, на чему сам им од срца захвална. (Велмар Јанковић, 7); Među takva (c) se djela bez sumnje uvrštava i Kantova Kritika čistog uma jer bez njenog poznavanja ne može se voditi nijedan filozofski dijalog $[\rightarrow$ само са њеним познавањем // уз њено познавање може се водити дијалог $\leftarrow$ не може се водити филозофски дијалог а да се при том не познаје] koji slijedi poslije nje, slagao se s njom ili ne. (В. Филиповић, 39); Ово без велике штете неће моћи да прође $[\rightarrow$ Ово ће моћи да прође само са великом штетом // уз велику штету $\leftarrow$ Неће моћи да прође а да при том не буде велике штете]. (И. Андрић $\left.{ }^{2}, 125\right)$; Исто тако није умела да исприча садржину ничијег казивања без опонашања његовог говора и његових покрета и без сликовитог и заморног описиваьа његове личности и средине у којој се креће [ $\rightarrow$ умела је да исприча садржину нечијег казивања само са опонашањем // уз опонамање његовог говора и његових покрета и са сликовитим и заморним описивағем његове личности и средине у којој се креће // уз сликовито и заморно описивање његове личности и средине у којој се креће // није умела да исприча садржину нечијег казивања а да при том не опонаша његов говор и његове покрете $и$ не описује сликовито и заморно његову личност и средину у којој се креће]. (И. Андрић², 174); итд.

И приликом множења негација у овом типу конструкција могу се јавити извесна ограничења, какав случај имамо у примеру: Што напрсне било би закрпљено; што се нагне, подупрто; али пре тога и мимо тога нико не би без потребе и са планом и предвиђанем стварао посао $\left[\rightarrow{ }^{*}\right.$ свако би стварао посао само са потребом и са планом и предвиђањем]. (И. Андрић $\left.{ }^{1}, 168\right)$, у којем множење негација онемогућава напоредна употреба генитивне предлошкопадежне конструкције са предлогом без и инструменталне конструкције са предлогом $c a$ уз исти негирани предикат.

\section{4. Множење негација између негираног предиката и негираног предикатског апозитива}

Логичко-математички принцип множења негација остварује се и реченицама са негираним предикатом и негираним предикатским апозитивом. Множењу негација, тако, подлежу (i) негација коју садржи глагол у предикату и (ii) негација коју садржи негирани придев ${ }^{9}$ у функцији предикатског апозитива, у чијем се резултату добија потврдна семантичка вредност двоструко негираног исказа.

...iz nemilosrdne bitke ravnopravnih protivnika, kao iz krvave borbe petlova, niko ne izlazi neoštećen $[\rightarrow$ сви излазе оштећени], bez obzira na to kome će pripasti tašta slava pobednika. (Д. Киш', 35); Čovek moje generacije nikada ne bi izašao u grad neobrijan $[\rightarrow$ uvek bin u grad izašao obrijan], možda u gaćama da, ali neobrijan ne. (Cosmopolitan, 15.8.2011, 12); итд.

9 Лексичком негацијом сматрамо негацију именичких, придевских, прилошких и заменичких речи, која се остварује домаћим префиксима не- и без- (код именица, придева и прилога) и префиксом ни- (код заменица и заменичких прилога), и префиксима страног порекла $a$-, $\partial и c-$, и- и $и н$ - 
И када је у функцији предикатског апозитива супстантивна синтагма са негираним конгруентним атрибутом, до множења негација долази између негације коју садржи предикат и негације коју садржи придев у функцији конгруентног атрибута: Није требало да дође невезаних руку $[\rightarrow$ Требало је да дође везаних руку]. (Д. Ћосић, 184); итд.

До множења негација између негираног предиката и негираног предикатског апозитива неће долазити у случајевима када је више предикатских апозитива у напоредном односу, при чему нису сви од њих негирани. У таквим случајевима двоструко негирани искази нису еквивалентни афирмативним исказима, будући да би заменом двоструко негираног исказа афирмативним еквивалентом, дошло до промене смисла исказа јер се и остали предикатски апозитиви који нису негирани односе на исти негирани предикат, па између њих не долази до множења негација, као у примеру Мали, грбави тумач није могао да живи тако непримећен, ограничен на своје основне дужности и сузбијен у свима својим неодољивим нагонима и утврђеним навикама $\left[\rightarrow{ }^{*}\right.$ морао је да живи примећен, ограничен... и сузбијен...]. (И. Андрић, 374); итд.

\section{5. Множење негација између негираног предиката и негираног објекта}

Множење негација остварује се и у реченицама са негираним предикатом и правим или неправим објектом израженим неком негираном именицом или супстантивном синтагмом са конгруентним атрибутом израженим неким негираним придевом. Множење негација остварује се тако између (i) негације коју садржи глагол у предикату и (ii) негације коју садржи негирана именица у функцији објекта или негирани придев у функцији конгруентног атрибута уз именицу у функцији објекта:

Рафаило се почео невољно мрдати као нељубазни домаћин који неће да прими незваног госта $[\rightarrow$ који хоће да прими само званог госта]. (В. Николић, 53); Pragmatičan sam čovek, jasno definišem probleme i precizno postavljam zadatke, mnogo radim, ali zato i od svojih saradnika tražim da me u tome prate i nikada ne obećavam nemoguće $[\rightarrow$ увек обећавам само могуће]. (http://www.sportske.net/vest/domaci-fudbal/covic-i-dzajic-i-ja-volimo-zvezduali-112416.html 24.1.2013); Из тог разлога, Едипа никад неће пронаћи недвосмислен одговор $[\rightarrow$ увек ће пронаћи само двосмислен одговор] на питање.... (Наслеђе 21, 2012, 233); Рана не трпи неуку руку [ $\rightarrow$ трпи само искусну руку] (Д. Ненадић, 24); итд.

У реченицама у којима објекат, изражен негираном именицом или супстантивном синтагмом са негираним придевом у функцији конгруентног атрибута, стоји у напоредном односу са објектом израженим неком другом ненегираном именицом или супстантивном синтагмом која не садржи негирани придев у функцији конгруентног атрибута не долази до множења негација, као у примеру Они не воле неповољне вести ни тешке мисли, ни озбиљне и брижне разговоре на капији $[\rightarrow *$ Они воле повољне вести и тешке мисли и 
озбиљне разговоре на капији], али виде и сами да ово не слути на добро. (И. Андрић $\left.{ }^{1}, 112\right) ;$ итд.

Да укратко закључимо, множење негација између различитих реченичних чланова остварује се у монопредикатским реченицама у којима је предикат реченице нужно негиран, док је други реченични члан који ступа у ово множење неки негирани глаголски додатак (или његов део) одредбеног или допунског карактера. Како је анализа примера показала, то може бити одредба начина изражена неким негираним начинским прилогом, логички субјекат уз глагол немати или не постојати, предикатски апозитив изражен негираним придевом, негирани објекат или одредбени члан исказан генитивном предлошкопадежном конструкцијом са предлогом без. До множења негација, заправо, долази између негације коју садржи предикат реченице и негације коју садржи лексема у функцији поменутих реченичних чланова, док се у резултату добија афирмативна семантичка вредност читавог исказа.

\section{ИЗВОРИ}

И. Андрић: Иво Андрић, Травничка хроника, Сарајево: Свјетлост, 1951.

И. Андрић ${ }^{1}$ : Иво Андрић, На Дрини ћуприја, Сабрана дела Иве Андрића, књига прва, Београд: Просвета, Загреб: Младост, Сарајево: Свјетлост, Љубљана: Државна заложба Словеније, Скопје: Мисла, Титоград: Побједа, 1981.

И. Андрић²: Иво Андрић, Госпођища, Сабрана дела Иве Андрића, књига трећа, Београд: Просвета, Загреб: Младост, Сарајево: Свјетлост, Љубљана: Државна заложба Словеније, Скопје: Мисла, Титоград: Побједа, 1981.

C. Бacapa: Svetislav Basara, Fama o biciklistima, Beograd: Dereta, 2007.

C. Велмар Јанковић: Светлана Велмар Јанковић, Бездно, Београд: Време књиге, 1995.

Д. Киш: Danilo Kiš, Grobnica za Borisa Davidoviča, Zagreb: Globus, Beograd: Prosveta, 1983.

Д. Ковачевић: Dušan Kovačević, Radovan Treći, u: Drame, Beograd: BIGZ, 1983.

Д. Ненадић: Добрило Ненадић, Доротеј, Београд: Политика, 2005.

В. Николић: Видан Николић, Проклета Јерина, Чачак: Легенда, 2007.

Д. Ћосић: Добрица Ћосић, Корени, Нови Сад: Матица српска, Београд: Српска књижевна задруга, 1970. 
Политика, дневне новине

Вечерне новости, дневне новине

Cosmopolitan, месечне новине

\section{ЛИТЕРАТУРА}

Бернини/Рамат 1996: Giuliano Bernini, Paolo Ramat, Negative Sentences in the Languages of Europe, Berlin: Mouton.

Бондаренко 1983: Виктор Николаевич Бондаренко, Отрицание как логикограмматическая категория, Moskva: Nauka.

Ван дер Аувера 2010: Johan Van der Auwera. On the Diachrony of Negation, The Expression of Negation, Laurence R. Horn (ed.), Berlin, New York, 73-111.

Ван дер Вуден 1995: Ton Van der Wouden, Litotes and downward monotonicity, Negation: A Topic in Focus, Heinrich Wansing (ed.), Berlin, 1-19 (dostupno na http://www.tonvanderwouden.nl/index_files/papers/ leipzig.pdf).

Веселинова 2009: Ljuba Veselinova, Standard and special negators in the slavonic languages: synchrony and diachrony, Wiener Slawistischer Almanach, 74, 195-208.

Дал 1979: Osten Dahl, Typology of Sentence Negation, Linguistics, 17, 79-106.

Живон 1978: T. Givon, Negation in language: pragmatics, function, ontology, Syntax and Semantics: Pragmatics, Peter, Cole (ed.), 9, New York, 69-112.

Јесперсен 1917: Otto Jespersen, Negation in English and other languages, Kobenhavn: Hovedkomissionaer Andr. Fred. Host \& Son, Kgl. Hof-Boghandel (доступно на http://archive.org/stream/cu31924026632947\#page/ n5/mode/2up).

Катичић 2002: Radoslav Katičić, Sintaksa hrvatskoga književnog jezika, Zagreb: Hrvatska akademija znanosti i umjetnosti, Nakladni zavod Globus.

Ковачевић 2002: Милош Ковачевић, Синтаксичка негаиија у српскоме језику, Ниш: Издавачка јединица Универзитета у Нишу.

Ковачевић 2004: Милош Ковачевић, Огледи о синтаксичкој негацији, Српско Сарајево: Завод за уџбенике и наставна средства. 
Ковачевић 2012: Милош Ковачевић, Узрочно семантичко поље, Београд: Јасен.

Кубурић Мацура 2005: Мијана Кубурић Мацура, Конструкције без + N(Gen) у функцији исказивања пропратне околности у Андрићевом роману Госпођица, Српски језик, X/1-2, 565-576.

Кшишкова 1968: Helena Kržižkova, K вопросу о так называемой двойной негации в славянских јазыках, Slavia XXXVII/1, Praha, 21-39.

Лашкова 1976: Лили Лашкова, Кьм характеристиката на синтактичното отрицание в србохрватски и блгарски език, Зборник Матице српске за филологију и лингвистику, XIX/1, 19-27.

Московљевић 1996: Јасмина Московљевић, О подизању негације у српском језику, Јужнословенски филолог, LII, 89-98.

Мршевић Радовић 1977: Драгана Мршевић Радовић, Глаголи супротног значења, Кюижевност и језик, 2-3, 226-237.

Мунен 1981: Žorž Munen, Lingvistika i filozofija, Beograd: BIGZ.

Павловић 1967: Миливоје Павловић, Негационе вредности у реченици, Годишьак Филозофског факултета у Новом Саду, књига Х, 241-256.

Петковић 2009: Јелена Петковић, Синтаксичка негација у светлу математичке и логичке негације, Савремена проучавања језика и књижевности I/1, М. Ковачевић и др. (ур.), Крагујевац, 75-83.

Петковић 2015: Јелена Петковић, Синтакса и семантика двоструке негащије у српском језику, необјављена докторска дисертација, Крагујевац.

Петровић 1998: Gajo Petrović, Logika, Novi Sad: Dnevnik, Beograd: Zavod za udžbenike i nastavna sredstva.

Прешић 1979: Marica Prešić, Slaviša Prešić, Uvod u matematičku logiku, Beograd: Matematički institut.

Радовановић 1977: Milorad Radovanović, Imenica u funkciji kondenzatora (I), Зборник Матице српске за филологију и лингвистику, XX/1, 63-144.

Симеон 1969: Rikard Simeon, Enciklopedijski riječnik lingvističkih naziva, Zagreb: Matica hrvatska.

Тугенхат/Волф 2000: Ernst Tugendhat, Ursula Volf, Logičko-semantička propedevtika, Vrnjačka Banja: Narodna biblioteka „Dr Dušan Radić”. 
Хорн 2001: Laurence Horn, A natural history of negation, Chicago: University of Chicago Press, (доступно на http://emilkirkegaard.dk/en/wp-content/ uploads/A-natural-history-of-negation-Laurence-R.-Horn.pdf).

Хорн 2010: Laurence Horn, Multiple negation in English and other languages, The Expression of Negation. Laurence R. Horn (ed.), Berlin - New York: Walter de Gruyter, 111-149.

Шарић 2007: Ljiljana Šarić, Antonimija u hrvatskome jeziku: semantički, tvorbeni i sintaktički opis, Zagreb: Hrvatska sveučilišna naklada.

\section{MULTIPLICATION OF NEGATION AMONG DIFFERENT SENTENCE CONSTITUENTS}

\section{Summary}

The paper examines multiplication of negation among different sentence constituents using the corpus containing variety of different functional styles. Multiplication of negation in a sentence, as the paper describes, is achieved between two negated sentence constituents out of which one needs to be sentence predicate, while other one can be logical subject, object, predicative appositive, adverb of manner or adverbial constituent represented with genitive-adverbial-case construction containing preposition bez. Analyzing the gathered examples further, it was concluded that in each of these cases, for multiplication of negations among two sentence constituents to happen both mandatory and optional conditions need to be fulfilled, whereby certain limitations were also noticed which prevent multiplication to be achieved.

Key words: negation, multiplication of negations, negated predicate, logical subject, object, predicative appositive, adverb of manner. 